\title{
Microbiological Quality of Local Market Vended Freshly Squeezed Fruit Juices in Dhaka City, Bangladesh
}

\author{
M. Shakir Uddin Ahmed, Tania Nasreen, Badrunnessa Feroza and Sahana Parveen* \\ Institute of Food Science and Technology, Bangladesh Council of Scientific and Industrial Research. \\ Dhanmondi, Dhaka-1205, Bangladesh.
}

\begin{abstract}
Freshly squeezed or freshly prepared fruit juices sold by local market vendors in Dhaka city were analyzed for the microbiological quality. Total viable bacterial counts, fungal counts, total coliform, faecal coliform and the presence of pathogenic microorganisms such as E. coli, Bacillus cereus, Staphylococcus aureus, Salmonella, Streptococcus were analyzed by standard methods. The total viable count of samples ranged from $3.00 \times 10^{2}$ to $9.60 \times 10^{8}$ and fungal counts ranged from $1.00 \times 10^{2}$ to $8.05 \times 10^{4}$. Out of 114 freshly prepared fruit juices samples collected 113 samples (99\%) showed the presence of coliform and E. coli. The other bacteria like B. cereus, Staphylococcus aureus, Salmonella, Streptococcus were found in 64.91\%, 6.14\%, 7.89\% and (5.26\%) of the tested samples. The number and type of microorganisms recovered from the freshly squeezed fruit juices made them unsafe for drinking. It was concluded that due to unhygienic fruit handling in the unsanitary environmental conditions under which the vendors operate the juices become contaminated with harmful bacteria. The results of this study demonstrate the unhygienic quality of popular types of market vended freshly squeezed fruit juices and their risk to the consumers.
\end{abstract}

Key Words: Fruit juices, Microorganisms, Contamination, E. coli, Microbiological quality standards.

\section{Introduction}

Fruit juices are well recognized for their nutritive values, minerals and vitamin contents. In many tropical countries they are common beverages and are sold at all public places and roadsides shops. However in view of their ready consumption, quick methods of cleaning, handling and extraction of the fruit juices are often prove to be an potential health hazard. There are reports of food borne illness associated with the consumption of fruit juices of several places of India and elsewhere (Sandeep et al. 2001). There have been some notable outbreaks of illness in recent years that demonstrate the increasingly important role of fresh fruits and vegetables in food borne disease (Parish, 1997 and Sandeep et al. 2001).

Consumption of fresh fruits continues to increase in many countries owing to consumer preferences for fresher, more nutritious foods that also happen to meet the needs of busier lifestyles. In addition to their increasing popularity in consumption patterns, fresh fruits and vegetables have also become increasingly important vehicles in food borne disease statistics (Sivapalasingam et al. 2004).

\footnotetext{
* Corresponding author: E-mail:
}

Contamination of fruit juices sold in restaurants, cafes and even road sides stalls are sometimes unacceptable for human consumption and creates significant health problems. Most of the sellers have on site facilities for extracting the juice from fresh fruits like orange, bananas, mangoes, papaya, watermelons, mixed of them and any other fruits that may be available. After preparation the sellers then serve the juices with ice to their thirsty customers. Juices are extremely pleasant and they contain most of the minerals and vitamins found in the original fruits but bearing in the mind the sellers method of extraction, an inevitable question arise over microbial safety. For example the outside of the fruit may not be washed properly before it is placed for extracting juice and even if it is washed the total colony count may be exceeded $1.0 \times 10^{5} \mathrm{cfu} / \mathrm{cm}^{2}$ (Bryan, 1977). Clearly many of these microorganisms shall be harmless yeasts or saprophytic bacteria but confidence does not mean that pathogens like Listeria monocytogens or Escherichia coli may not be present as well (Bryan, 1977).

Fresh squeezed or pressed juices made from fruits and vegetables have a very high consumer preference both in terms 
of taste and health effects throughout the world, however, such juices, especially unpasteurized juices have been shown to be a potential source of bacterial pathogens notably, Salmonella, E.Coli O 157:H7 (Ryu et al. 1998, Uljas et al. 1998, Zhuang et al. 1995)

In Bangladesh, especially in the metropolitan and other big cities a huge section of the population of all income and age groups consume fresh pressed and squeezed juices, most of these juices are sold by local market vendors. In Dhaka, the capital city of Bangladesh, approximately $94 \%$ of the population, including tourists comprising of all age and income groups prefer and consume freshly squeezed or pressed juices particularly, mango, pineapple, papaya and apple, in considerable amounts during the months of March through August.

In view of the threat posed by the bacterial pathogens in juices and the flourishing demands of such local market and street vended juices, the present work was undertaken to assess the microbiological quality of freshly squeezed juices and their safety for human consumption in terms of bacterial pathogens.

\section{Materials and Methods}

During the study five locations in the Dhaka city were chosen for collection of samples. These were New Market (1), Elephant road (2), Mirpur road (3), Green road (4), Shahbag (5). Samples of fresh fruit juices were collected from at least 3 shops in each zone where the sale was approximately 100 glasses each day. Six varieties of fruit juices namely Mango, Papaya, Watermelon, Pineapple, Apple and Bael were cho sen based on the consumer demands. All the samples (124) were collected in sterile containers kept in the ice box maintaining $4^{\circ} \mathrm{C}$ during transportation to the laboratory and analyzed within 2 hours of collection. For Analysis $250 \mathrm{ml}$ of the sample was collected using the vendors own utensils and placed into sterile glass bottle which were kept in ice box during transportation to the laboratory and analyzed within 2 hours of collection.
Isolation and enumeration of bacteria were done by observing growth in selective media. For Total Viable Count (TVC) portion of juices were diluted as 1:10 using sterile phosphate buffer which were subsequently diluted with the same as needed and then enumerated for total viable count using nutrient agar. Since this is a one time study, 3-6 samples were collected from each location and surface plates were made in triplicates in appropriate selective media. Bacterial isolation was performed by pour plate method and fungal isolation was performed by spread plate method. Both bacterial and fungal enumerations were expressed as colony forming units (cfu) per ml. In all the cases counts were made up to 72 hours. Total coliforms were detected by MPN procedure according to standard method (APHA, 1985). Presence of faecal coliforms were determined using Brilliant Green Lactose Bile broth $\left(44.50^{\circ} \mathrm{C}\right.$ for 48 hours), followed by confirmation of gas positive tubes using Eosin methylene Blue agar. Inoculated plates were incubated at requisite time-temperature combinations ( FAO, 1917 and FDA, 2001). Staphylococcus aureus was enumerated using Baird Parker Agar. Isolates of Staphylococcus aureus obtained on Baird Parker agar were characterized for their production of coagulase, thermostable DNAse activity, catalase and hemolysine production and mannitol fermentation (FDA, 2001). For detecting the presence of Salmonella portions of juices were preenriched in Lactose Broth and then one loopful of sample was transferred to Selenite Broth and then positive samples were confirmed by streaking on Bismuth Sulfite Agar and then biochemically confirmed the presence of Salmonella. In all cases for confirmation of the pathogens typical colonies were identified on the basis of cultural, microscopic analysis and biochemical characteristics (Buchanan et al. 1974). All the media were obtained from Himedia Laboratories Limited, India.

\section{Results and Discussion}

Microbial count of different freshly prepared fruit juices were shown in the Table I. From the results it is clear that all

Table I. Microbial count of various freshly prepared fruit juices from five different locations in Dhaka city.

\begin{tabular}{l|c|c|c|c}
\hline $\begin{array}{l}\text { Type and number } \\
\text { (n) of fruit juice }\end{array}$ & $\begin{array}{c}\text { Total aerobic } \\
\text { bacterial count }(\mathrm{cfu} / \mathrm{ml})\end{array}$ & $\begin{array}{c}\text { Total coliform } \\
(\mathrm{MPN} / 100 \mathrm{ml})\end{array}$ & $\begin{array}{c}\text { Faecal coliform } \\
(\mathrm{MPN} / 100 \mathrm{ml})\end{array}$ & $\begin{array}{c}\text { Total fungi } \\
(\mathrm{cfu} / \mathrm{ml})\end{array}$ \\
\hline Mango (n=24) & $8.00 \times 10^{3}-8.05 \times 10^{8}$ & $1100->2400$ & $7->2400$ & $1.05 \times 10^{2}-8.05 \times 10^{4}$ \\
Papaya (n=22) & $1.50 \times 10^{4}-7.16 \times 10^{7}$ & $1100->2400$ & $7->2400$ & $<1.00 \times 10^{4}-2.50 \times 10^{2}$ \\
Pineapple (n=18) & $2.50 \times 10^{4}-9.60 \times 10^{8}$ & $210->2400$ & $23->2400$ & $<1.00 \times 10^{2}-8.00 \times 10^{3}$ \\
Watermelon (n=15) & $3.00 \times 102-9.00 \times 10^{8}$ & $43-1100$ & $<3-20$ & $<1.00 \times 10^{1}-3.00 \times 10^{3}$ \\
Apple (n=15) & $9.17 \times 10^{4}-8.00 \times 10^{7}$ & $150->2400$ & $<3-23$ & $<1.00 \times 10^{1}-3.50 \times 10^{3}$ \\
Bael $(\mathrm{n}=20)$ & $2.30 \times 10^{3}-9.17 \times 10^{4}$ & $460->2400$ & $11->2400$ & $<1.00 \times 10^{1}-1.50 \times 10^{3}$ \\
\hline
\end{tabular}


the juices contain a significant amount of microorganisms. The mean total viable count (microbial load) showed the presence of bacteria in all the freshly prepared fruit juices in the range of $3.00 \times 10^{2}$ to $9.60 \times 10^{8}$.

Maximum samples contained higher load of microbes than the Gulf standard (Gulf Standards. 2000) for foods described in Table II. All the samples contain coliforms, ranged from 43 to $>2400 / 100 \mathrm{ml}$. Faecal coliform was present in all samples in the range of 7 to $>2400 / 100 \mathrm{ml}$. In the case of total coliforms it exceeds Gulf standard for most of the cases.

Table II. The recommended Microbiological standards for any fruit juices sold in the Gulf Region (Gulf Standard 2000)

\begin{tabular}{l|c|c|c}
\hline Test & $\begin{array}{c}\text { Total aerobic } \\
\text { bacterial count } \\
(\mathrm{cfu} / \mathrm{ml})\end{array}$ & $\begin{array}{c}\text { Total coliforms } \\
(\mathrm{cfu} / \mathrm{ml})\end{array}$ & $\begin{array}{c}\text { Yeasts and } \\
\text { molds } \\
(\mathrm{cfu} / \mathrm{ml})\end{array}$ \\
\hline $\begin{array}{l}\text { Maximum } \\
\text { count } \\
\text { anticipated }\end{array}$ & $5.0 \times 10^{3}$ & 10 & 100 \\
\hline $\begin{array}{l}\text { Maximum } \\
\text { count } \\
\text { permitted }\end{array}$ & $5.0 \times 10^{4}$ & 100 & $1.0 \times 10^{3}$ \\
\hline
\end{tabular}

From Table III it can be found that faecal contamination and the concomitant presence of Salmonella (in $7.89 \%$ of 124 samples) was a cause of concern: it is possible that Salmonella may have gained entry through water because vendors do not use boiled water and WASA water in Dhaka city is highly contaminated (Parveen et al. 2008) and this water is commonly used for diluting juices or other ingredients and utensils used for washing and preparing juices, alternately, the possibility of contamination of fruits through improperly treated irrigation water cannot be ruled out; survival and entry of enteropathogens including Salmonella have been shown in crops, irrigated with contaminated sewage (Beuchat, 1998).

Only seven samples of juices (7.89\%) showed the presence of coagulase positive Staphylococcus aureus, the presence of coagulase positive Staphylococcus aureus in juices indicate severe contamination through handling. The entry of Staphylococcus aureus in juices, may be attributed to contact with the outer surface of fruits during juicing, survival and growth of foodborne pathogens on surfaces of fruits and vegetables have been demonstrated (Banwart, 1989).

Bacillus cereus was present in $64.91 \%$ of the samples. Streptococcus also present in $5.26 \%$ of juices. Total fungi

Table III. Microorganisms isolated from various freshly prepared fruit juices ( $N=114)$.

\begin{tabular}{|c|c|c|c|c|}
\hline $\begin{array}{l}\text { Microorganism } \\
\text { identified }\end{array}$ & Type of fruit juice & $\begin{array}{c}\text { Number of sample } \\
\text { tested }\end{array}$ & $\begin{array}{l}\text { Number and } \\
\text { frequency (\%) }\end{array}$ & $\begin{array}{l}\text { Overall number and } \\
\text { total frequency (\%) }\end{array}$ \\
\hline \multirow{6}{*}{ Escherichia coli } & Mango & 24 & $24(100 \%)$ & \multirow[t]{6}{*}{$113(99 \%)$} \\
\hline & Papaya & 22 & $22(100 \%)$ & \\
\hline & Pineapple & 18 & 18 (100\%) & \\
\hline & Watermelon & 15 & 14 (93.33\%) & \\
\hline & Apple & 15 & 15 (100\%) & \\
\hline & Bael & 20 & 20 (100\%) & \\
\hline \multirow{6}{*}{ Bacillus cereus } & Mango & 24 & 16 (66.67\%) & \multirow{6}{*}{ 16(64.91\%) } \\
\hline & Рapaya & 22 & 14 (63.63\%) & \\
\hline & Pineapple & 18 & 10 (55.56\%) & \\
\hline & Watermelon & 15 & $10(66.67 \%)$ & \\
\hline & Apple & 15 & $8(53.33 \%)$ & \\
\hline & Bael & 20 & $16(80 \%)$ & \\
\hline \multirow{4}{*}{ Salmonella } & Mango & 24 & $3(12.50 \%)$ & \multirow{4}{*}{$9(7.89 \%)$} \\
\hline & Рapaya & 22 & 2 (9.09\%) & \\
\hline & Watermelon & 15 & 3 (20\%) & \\
\hline & Bael & 20 & $1(5 \%)$ & \\
\hline \multirow{4}{*}{ Staphylococcus aureus } & Mango & 24 & $1(12.50 \%)$ & \multirow{4}{*}{7 (6.14\%) } \\
\hline & Papaya & 22 & 2 (9.09\%) & \\
\hline & Watermelon & 15 & 3 (20\%) & \\
\hline & Bael & 20 & 1 (5\%) & \\
\hline \multirow{3}{*}{ Streptococcus } & Mango & 24 & $3(12.50 \%)$ & \multirow{3}{*}{$6(5.26 \%)$} \\
\hline & Рapaya & 22 & 1(9.09\%) & \\
\hline & Watermelon & 15 & $2(20 \%)$ & \\
\hline
\end{tabular}


counts are also higher in the range of $1.0 \times 10^{1}$ to $8.05 \times 10^{4}$ $\mathrm{cfu} / \mathrm{ml}$ respectively. In the present studies the fruits would be contain large numbers of vegetative bacteria and also have been further contaminated at the vending sites during cutting, chopping, and mixing. Usually vendors cut these materials holding them in their bare hands. In addition raw materials were left uncovered on the tables during the preparation which allowed for dust to settle leading to further contamination. Dirty knives were also used to cut this fruits. The ice and water added during preparation were likely to provide possible sources of additional bacterial contamination (Bryan et al. 1998, Bryan et al. 1992, ICMSF, 1998). Furthermore, these fruit juices were left in ambient temperature which may have led to the proliferation of contaminating bacteria resulting in increased bacterial counts (Bryan et al. 1977 and Bryan et al. 1992).

It was thus concluded that the lack of hygiene, holding time during the preparation of fruits and contaminated source of ingredients are major detrimental for the quality. Poor hygienic quality of these juices and consumers are placed at a risk of contracting clearly food borne infections.

\section{Conclusion}

The practice of consuming fresh fruit or vegetable juices cannot be stopped on nutritional grounds nor the street vendors prohibited from selling such items since such activities provide them with a source of livelihood, government agencies such as Bangladesh Council of Scientific and Industrial Research (BCSIR) and Bangladesh Standard and Testing Institution (BSTI) must adopt measures to educate the vendors about food safety and hygienic practices and enforce adequate guidelines for juices especially freshly prepared juices: such norms and conventions, currently do not exist in Bangladesh.

\section{References}

American Public Health Association. (1985) Standard methods for the examination of water and wastewater, 16th Ed. APHA Inc. Washington D.C. pp 1268.

Banwart G. J. (1989) Basic Food Microbiology, 2nd ed. Van Nostrand Reinhold, NewYork, NY. pp 115-117.

Beuchat R. L. (1998) Surface decontamination of fruits and vegetables eaten raw; a review, Food Safety Unit, World Health organization. pp 468-482.

Bryan F. L. (1977) Diseases transmitted by foods contaminated with wastewaters. J. Food Protection. 40: 45-56.

Bryan F. L., Teufel P., Riaz S., Roohi S., Qadar F. and Malit Z. (1992) Hazards and critical control points of vending operations at a railway station \& bus station in Palaitar. Journal of Food Protection. 55: 534-541.

Bryan F. L., Teufel P., Riaz S., Roohi S., Qadar F. and Malit, Z. (1992) Hazards and critical control points of vending operations in a mountain resort town in Palaitar.
Journal of Food Protection. 55: 701-707.

Bryan F. L., Michanie S. C., Alvarez P. and Paniagua A. (1998) Critical control points of street vended foods in the Dominican Republic. Journal of Food Protection. 51: 373-383.

Buchanan R. E., and Gibbon N. E. (1974) Bergey's Manual of Determinative Bacteriology. 8th Ed. (The Williams \& Wilkisn Co. Baltimore). pp 293-312.

Food and Agriculture Organization. (1979) Manual of Food Quality Control. 4, Microbiological Analysis. FAO. Rome. pp 1-32.

Gulf Standards. (2000) Microbiological Criteria for Foodstuffs-Part 1. GCC, Riyadh, Saudi Arabia.

International Commission on Microbiological Specifications for Foods. (1998). Microorganisms in Foods, Microbial Ecology of Food Commodities. 6: 615-616.

Parish M. E. (1997) Public health and non pasteurized fruit juices. Crit. Rev. Microbiol. 23:109-119.

Parveen S., Ahmed M. S. U. and Nasreen T. (2008) Microbial Contamination of water in around Dhaka city. BJSIR. 43(2): 273-276.

Ryu J. H. and Beuchat L. R. (1998) Influence of acid tolerance responses on survival, growth, and cross- protection of Escherichia coli O157:H7 in acidified media and fruit juices. Int. J. Food Microbiol. 45: 185-193.

Sandeep M. D., Waker A. and Abhijit G. (2001) Microbiological Analysis of street vended fresh squeezed carrot and kinnow-mandarin juices in Patiala city, India. Internet Journal of Food Safety. 3: 1-3.

Sivapalasingam S., Friedman C. R., Cohen L. and Tauxe R .V. (2004) Fresh produce: a growing cause of outbreaks of foodborne illness in the United States, 1973 through 1997. J Food Prot .67: 2342-2353.

Uljas H. E. and Ingham S. C. (1998) Survival of Escherichia coli 0157:H7 in synthetic gastric fluid after cold and acid habituation in apple juice or trypticase soy broth acidified with hydrochloric acid or organic acids . $J$. Food Prot. 61: 939-947.

U.S. Food \& Drug Administration, CFSAN. (2001) Bacteriological Analytical Manual Online. Chapter 12. pp 1-6.

Zhuang, R. Y. Beuchat, L. R. Angulo, F. J.(1995) Fate of Salmonella montevideo on and in raw tomatoes as affected by temperature and treatment with chlorine. Appl. Environ. Microbiol. 61: 2127-2131.

Received : October, 20, 2008;

Accepted : April, 27, 2009 